\title{
A Multi-Criteria Assessment of Industrial Zones' Attractiveness Scores in Viet Nam
}

\author{
NGUYEN Duc Thanh \\ Viet Nam Center for Economic and Strategic Studies (VESS), Ha Noi, Viet Nam. \\ Email: thanh.nguyenduc@vess.org.vn (Corresponding Author) \\ LE Huong-Linh \\ International School, Vietnam National University, Hanoi, Viet Nam. \\ Email: linhlh@isvnu.vn \\ BUI Thi Thuy Linh \\ Viet Nam Institute for Economic and Policy Research (VEPR), Ha Noi, Viet Nam. \\ Email: bui.thuylinh@vepr.org.vn
}

\begin{abstract}
Since the first industrial zones (IZ) was established more than two decades ago, the number of IZs in Viet Nam has mushroomed to meet the demand of national industrial development. However, it is challenging for enterprises, IZs' infrastructure developers, policy-makers and other users to assess the competence of IZs for their location decisions due to the substantial number of IZs, the insufficiency of information of IZs, the lack of suitable and reliable ranking methods and the absence of a ready-made ranking of all IZs in Viet Nam. Thus, there is an urgent need to identify precisely the 'attractiveness' level of the existing IZs based on their own characteristics or in other words, to make a ranking of IZs nationwide. Toward this purpose, this study applied the multi-criteria analysis method to rank the IZs in Viet Nam. This paper is the first ever to successfully conduct a ranking of IZs in Viet Nam with a database constructed at both macro and micro levels, including local economic environment, accessibility, infrastructure, and financial expenses. The ranking is expected to be a useful instrument for enterprises to choose their locations as well as for IZs' infrastructure developers to measure the attractiveness levels of their IZs to develop better business plans. Moreover, it can be used as a basis for policy makers in IZs planning in a more reasonable and scientific manner.
\end{abstract}

Keywords: Location decisions, industrial cluster, industrial zone ranking, attractiveness scores, supply chain planning, Viet Nam.

\section{INTRODUCTION}

Industrial zones (IZs) in developing economies are generally created with the purpose of promoting industrialization and economic growth, particularly for job creation and foreign direct investment attraction. The role of IZs in enhancing economic growth is particularly explicit in countries that are at an early stage of industrial development (UNIDO, 2012). When choosing distribution centers (Gholamian and Nasri, 2019), production and business locations in general and choosing IZs in particular, investors often pay attention to several factors such as: transportation costs (Launhardt, 1993; Von Thunen, 1966; Weber, 1929), markets (Lösch, 1978), road infrastructure and demand dispersion (Mokrini et al., 2019), business's cost and benefit (Badri, 2007; Greenhut, 1956; Hoover, 1948; Lösch, 1978; Mota and Brandão, 2013; Samuelson, 1938; Snyder and Nicholson, 2008), technology and human capital (ArauzoCarod et al., 2010), public good (Gabe and Bell, 2004), environmental regulation (Becker and Henderson, 2000; List and McHone, 2000), support from public administration (Friedman et al., 1992; Woodward, 1992), institutional quality (Knack and Keefer, 1995; Sachs and Warner, 1997), etc.

Investors may have different ways of choosing IZs, but they have a tendency to go through four steps: (i) gather information on IZs; (ii) use certain methods to analyze information about IZs based on criteria that they find important; (iii) create a ranking of the attractiveness of IZs according to certain priority orders; and (iv) select preferred IZ based on priority in the ranking in step (iii). It should be noted that each assessor has different concerns and priorities. For example, some people value convenience in terms of traffic and quality of IZ infrastructure over the rental price of the IZ and vice versa. Therefore, the attractiveness of the IZ in each investor's perception is different.

In Viet Nam, it has been challenging for investors to find suitable IZs for their production sites for four main reasons. The first reason is the large number of IZs. Since the first zone was established, the number of IZs nationwide has reached more than 300 as of June, 2019 (Vietnamese Ministry of Planning and Investment, 2019). With such a sizeable number of IZs, manufacturers might struggle to select the suitable ones for their location.

The second reason, which is also linked to the first one, is the nonexistence of a comprehensive, reliable and comparable database of IZs. For judicious decisions, such an indispensable database should encompass both macro and external criteria such as institutions, local business environment, availability and quality of local labor, and micro or internal indicators directly connected to the IZ, including traffic convenience, area, rent price, quality of infrastructure, availability and price of services, and specific incentives. However, if data on Vietnamese IZs is available, 
it is likely to be sporadic, incomplete, undisclosed, and outdated.

The third reason is the lack of methods for IZ rankings in Viet Nam. Having had information about IZs, in order to choose an IZ, people often formulate different criteria and find out which IZ is suitable for those criteria. This is feasible given the small number of IZs and criteria. However, given a large number of IZs and criteria, it is essential to have an appropriate method for processing the huge amount of information. In fact, even when such a complete database exists, without knowing how to compare and analyze, it is difficult for stakeholders to find a suitable IZs that meets their own criteria. The appropriate method to use in this case is the multi-criteria analysis method. But this IZ ranking method has not been applied in Viet Nam.

Finally, rankings of IZs have not appeared yet in Viet Nam. The easiest and most usable way to select IZs without having the database or understanding the multi-criteria analysis method is to have a ready-made ranking of all IZs in Viet Nam. This ranking is the result of gathering and processing information of IZs using the above mentioned multi-criteria analysis method. Based on the IZ rankings, manufacturers, IZ infrastructure developers, managers and others can find the IZs that best suit them.

This study has overcome these limitations mentioned above. First of all, we built for the first time a comprehensive and elaborate database of all Vietnamese IZs at both macro and micro levels. To develop this database, we conducted a field survey covered the North, Central and South of Viet Nam, in-depth interviews and secondary data collection. To analyze this database, the research has inherited and improved the multi-criteria analysis method from Ramos and Fonseca (2016) to make a ranking assessing the 'attractiveness' levels of Vietnamese IZs. To our best knowledge, this is the pioneering study to rank Vietnamese IZs. With this ranking, businesses are expected to have a better choice of IZs for their location, IZ infrastructure developers are believed to develop more prudent business strategies and policy makers are supposed to have a wiser basis for state management of IZs.

The structure of this study consists of six parts as follows: subsequent to the introduction, the second section presents theories related to IZs and location decisions. In the third section, the formation and development of IZs in Viet Nam is analyzed. The fourth section focuses on the theories of ranking and their application in IZs in Viet Nam. Following the results and findings section, the study will draw some conclusion and suggest some important implications.

\section{LITERATURE REVIEW ON INDUSTRIAL ZONES DEVELOPMENT AND LOCATION DECISIONS THEORIES}

\subsection{Industrial Zones Development}

An IZ is a zone developed and divided into lots according to a comprehensive plan including internal roads, transportation facilities, and public works. IZs may or may not have prefabricated buildings, as well as with or without common facilities for the use of a producer group (UNIDO, 1997). Developing IZs will help to bring about benefits for countries (UNIDO, 2012). Accordingly, the benefits of IZs come from the concept of 'industrial district' (Marshall, 2009) or the concentration of production activities in one location to meet requirements on climatic and soil conditions, raw materials, water sources and other necessary elements for production. Infrastructure provision would be smoother in a limited geographic area, particularly in places where national/state authorities have limited supplying competence (Belussi and Caldari, 2009). Additionally, UNIDO (2012) underlined that owing to IZs, provinces and nations have a chance to accelerate economic development by attracting innovative businesses, leading to both more jobs and a larger tax base. Moreover, start-ups, new enterprise incubation and knowledge-based businesses can be boosted in IZs because they offer an environment where local and international firms can interact with centers of knowledge creation. These entities can be considered as innovation hubs, promoting interactive learning and the commercialization of research outputs, and can exploit local entrepreneurial potential. As a result, a number of governments acknowledge the contribution of IZs to economic development, such as East Asia's "tiger economies" and in China during the 1980s, as well as in Europe, the Americas and parts of South Asia since as far back as the 1960s (Vidová, 2010).

\subsection{IZ Location Decisions Theories}

The location decisions theories then can be categorized into several branches, such as classical industrial location theory, economic location theory, neoclassical theory (new economic geography), institutional theory, and eclectic theory.

Classical location of industries theory: The Classical location of industries theory emphasizes the role of costcutting, particularly transportation costs (Launhardt, 1993; Von Thunen, 1966) in location decision. In this theory, Weber (1929) builds a spatial model of industrial location based on the principle of minimizing costs of transportation and labor. Various studies later used Weberian theory as a tool to better understand the decision-making process (Tellier and Vertefeuille, 1995).

Theory of economic location: Research on the theory of economic location (Lösch, 1978) is the modification of the central place theory (Christaller, 1966). While Christaller (1966) shows that the distribution of goods and the concentration of profits are entirely based on traffic and location, Lösch (1978) model emphasizes that the optimal location is the place that will bring the largest revenue or the largest market that can be monopolized. The cost-benefit model was later developed by numerous studies such as Hoover (1948) and Greenhut (1956). When choosing a location, firms consider factors to reduce input costs or increase output revenue (Badri, 2007; Greenhut, 1956; Hoover, 1948; Lösch, 1978; Mota and Brandão, 2013; Samuelson, 1938; Snyder and Nicholson, 2008).

New economic geography theory (Neoclassical theory) This line of theory explains regional economic disparities on the basis of effects of the spatial agglomeration. Krugman (1991) incorporates geographic and spatial categories into mainstream economics. Neoclassical theories consider that firms have perfect information for the selection of optimal locations, such as information about cumulative advantages (mainly population, number of workers), transportation infrastructure (spatial 
distribution, distance), and technology and human capital (Arauzo - Carod et al., 2010). Regions with easy access to welldeveloped transport infrastructure have the potential to minimize transportation costs for suppliers (inputs), distribution (outputs), labor (factors of production), and customers (profit) (Maroto and Zofío, 2016).

Institutionalist theory: The Institutionalist theory highlights the influence of institutions on the investment decision-making process of enterprises. Formal institutions and informal institutions have certain influences on business performance (Hoffman and Schniederjans, 1994). Institutional theory rejected neoclassical approaches which focused too much on the economic aspect of everyday life (Kušar, 2011). Institutions can be public good (Gabe and Bell, 2004), environmental regulation (Becker and Henderson, 2000; List and McHone, 2000), public administration support (Friedman et al., 1992; Woodward, 1992), institutional quality (Knack and Keefer, 1995; Sachs and Warner, 1997), corruption index, and ministry quality administrative machines (Mauro, 1995).

Eclectic theory: The eclectic theory shows that the three factors of OLI (Ownerhsip - Location - Internalization) or advantage of ownership, advantage of location advantage and internalization can affect investment decisions. Of these three factors, location advantage is the advantage that an enterprise can gain from conducting business in a certain location with specific characteristics such as infrastructure, market, natural resources, policies, human resources, etc. (Dunning and Lundan, 2008).

In a nutshell, to decide locations businesses are said to take into account numerous factors related to the locations to minimize cost and maximize profit such as transport cost, availability of transportation infrastructure, agglomeration or networks with suppliers and competitors, natural and human resources, and local institutions. When it comes to IZs, the analysis of these factors reveals their attractiveness. The purposes of this study therefore are twofold: (i) to build a full database of IZs in Viet Nam; and from this (ii) to elaborate an IZ ranking by applying of the multi-criteria analysis method. The ranking will help users find the most suitable IZ based on their interest in its attractive level.

\section{A BRIEF HISTORY OF THE DEVELOPMENT OF INDUSTRIAL ZONES IN VIET NAM}

According to the Vietnamese Ministry of Planning and Investment (2017), IZs have been introduced in Viet Nam to lay the foundations of investment promotion and industry diversification, particularly export-oriented light industries. Compared to the previously developed export processing zone model, the IZ model proves to be more appropriate to the rapid growth of Vietnam's industrial development in the context of international integration. Consequently, a number of export processing zones have been converted to IZs. It was not until 1994 that the first IZ was brought in to being in Viet Nam (Vietnamese Ministry of Planning and Investment, 2017). Since then, the number of newly established IZs increased steadily annually, springing up the total number of IZs nationwide to 39 in 1997 . However, in the wake of the Asian financial crisis in 1997, the number of new IZs plummeted. In 2001, only one IZ was established (Vietnamese Ministry of Planning and Investment, 2017).

Following this contraction, the number of IZs exploded in the period of 2002 - 2008 owing to rapid economic growth and successful international economic integration of the country. Viet Nam did indeed achieve a high rate of economic growth of $7-8 \%$ per year during this period. In addition, becoming a member of the World Trade Organization in 2007, the economy showed a tendency to be more open with various tariff barriers were removed. Thanks to this positive influence, a number of new IZs had been registered for establishment. Impressively, 47 new IZs were established in 2008. After this climax, the number of new IZs has gradually decreased to less than 10 zones per year. By the end of June 2019, Viet Nam has 326 IZs with the total natural area of nearly 93 thousand hectares, of which industrial area accounted for $68 \%$ (Vietnamese Ministry of Planning and Investment, 2019) (see Figure 1).

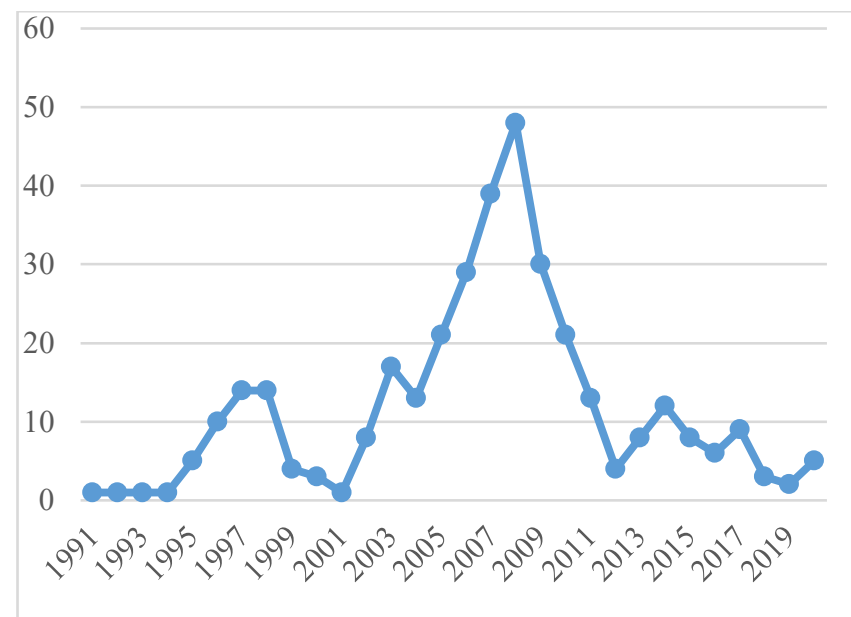

Figure 1. Number of industrial zones established by year Source: Compiled from data of Vietnamese Ministry of Planning and Investment

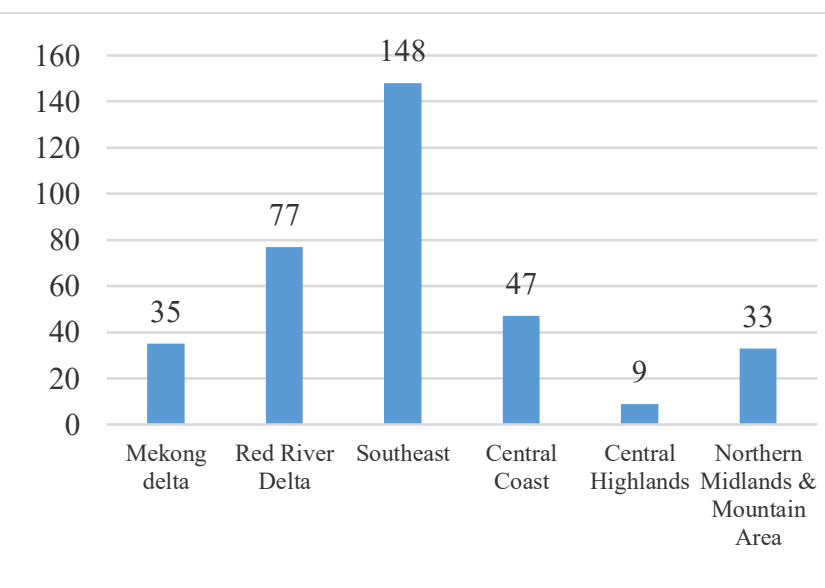

Figure 2. Number of Industrial Zones by geographic area Source: Compiled from data of Vietnamese Ministry of Planning and Investment

Despite such a large number, these IZs are geographically unevenly distributed. They concentrate the most in the Southeast region (accounting for 42.04\%) and then the Red River Delta (22.06\%). In each region, IZs also 
congregated in certain provinces and cities (see Figure 2). For instance, in the Southeast region, IZ density in Binh Duong province stands as the highest with 36 zones, followed by Dong Nai (32 zones) and Ho Chi Minh City (25 zones). Viet Nam has emerged as one of the most open destinations for foreign participation in construction and management of IZ infrastructure. Enterprises could select IZs developed by state-owned, private, $100 \%$ foreign-owned, or joint-venture infrastructure developers for their location. The majority of IZ developers are Vietnamese private, who have built up to $62 \%$ of the number of IZs (see Figure 3). Most IZ foreign developers are from Asia such as China, Taiwan, Singapore, South Korea and Japan.

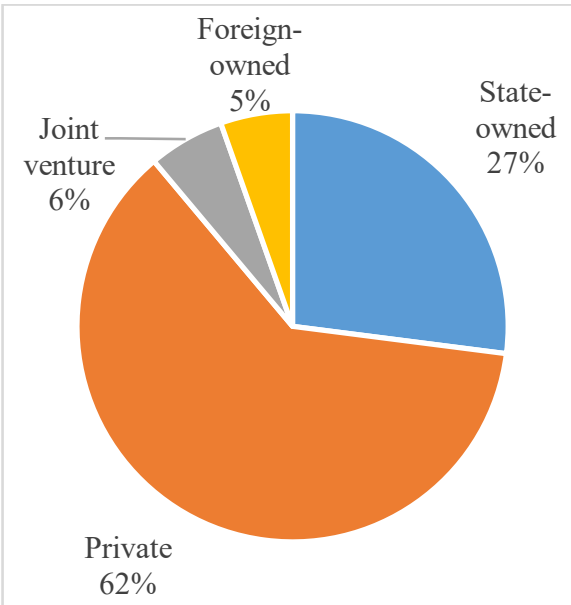

- State-owned

- Private

- Joint venture

- $100 \%$ foreignowned

Private

Figure 3: Type of ownership of industrial zones

Source: Compiled from figures of Department of Economic Zone Management - Ministry of Planning and Investment

After 25 years of development, the IZ model in Viet Nam has achieved certain success. Annually, the foreign direct investment (FDI) in IZs accounts for about $60 \%$ to $70 \%$ of the total FDI capital attracted in Viet Nam (Vietnamese Ministry of Planning and Investment, 2017). By the end of 2018, more than 7,300 domestic projects and 8,000 FDI projects with a total registered capital of 36 billion USD and 145 billion USD, respectively chose IZs as their location (Vietnamese Ministry of Planning and Investment, 2018).

IZs also give Viet Nam the much-awaited opportunity to join the global value chain by playing host to projects of multinational corporations such as Samsung, LG (Korea), Bosch (Germany), and Canon (Japan). Projects in IZs generate significant revenue and jobs, making a considerable contribution to the state budget. In 2018, their revenue reached 200 billion USD, accounting for $50 \%$ of the country's import and export turnover. These projects provided 3.3 million jobs, accounting for $23.17 \%$ of the workforce in the industry - construction sector (Calculated based on the data of the General Statistics of Viet Nam in 2018), and contributed to 85 trillion VND to the state budget in the same year (Vietnamese Ministry of Planning and Investment, 2018).

In short, IZs play an increasingly important role in Viet Nam. They provide infrastructure for industrial projects, separating manufacturing facilities from residential areas. Projects in the IZs provide jobs for the economy, significantly contributing to the state budget. With such a sizable number of IZs, a ranking which materializes the 'attractiveness' levels of the existing IZs is needed. Such a ranking could be utilized as a basis to help investors grade locations for their projects and policy makers conduct IZs planning in a more reasonable and scientific manner. To date, this is the first study ever to collect data on IZs in a systematic way, and construct a ranking index of IZs to meet all the above requirements.

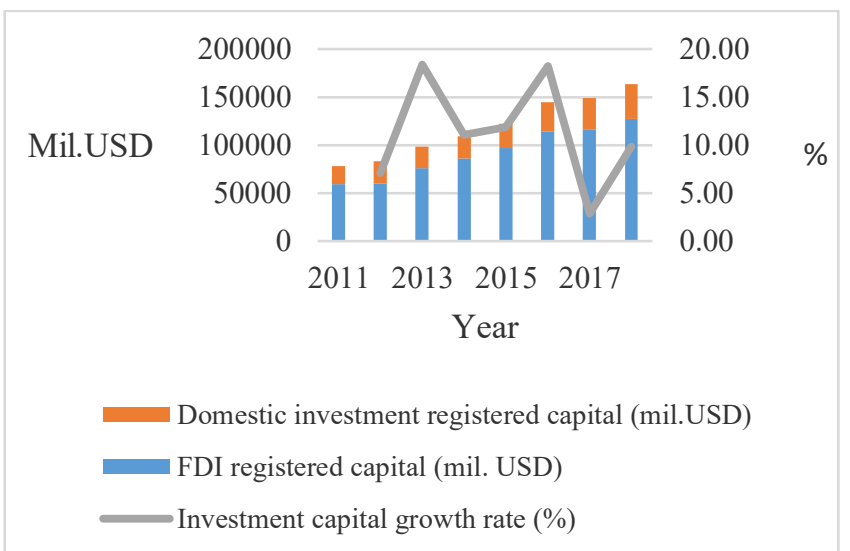

Figure 4. Investment into industrial zones in Viet Nam in the period of $2011-2018$

Source: Compiled from data of Department of Economic Zone Management - Ministry of Planning and Investment

\section{METHODOLOGY FOR RANKING INDUSTRIAL ZONES IN VIET NAM}

\subsection{Foundational Methodology of IZs' ranking}

This study utilizes the multi-criteria analysis method to conduct a nationwide ranking of Viet Nam's IZs. A comprehensive review of literature on the methodology had been done by Nguyen D. Thanh, Pham V. Dai and Vu M. Long (2019), who also proposed a theoretical framework for ranking all IZs in Viet Nam. Additionally, multi-criteria analysis performs the functions of a decision-making method widely used in various fields, from humanitarian supply chains (Kobayashi et al., 2019), economics, finance, investment, business, and resource management to traffic safety, health and technical design. The method is largely applied in various decision-making processes, namely multiattribute utility theory, analytical hierarchy process, data development analysis, and outranking methods (Velasquez and Hester, 2013). Ramos and Fonseca (2016) conducted a multi-criteria analysis method to support and improve the efficiency of industrial planning in Ave Valley, Portugal. The study first identified specific characteristics of IZs that might draw the attention of investors, such as infrastructure, service delivery capacity and accessibility (i.e. the ability to access routes, highways, seaports and airports). Then, the authors used a set of different criteria to evaluate the attractiveness of IZs, or in other words, a ranking of the potentiality of IZs to attract investment.

Besides, the integration of the geographic information system (GIS) with the multi-criteria analysis method has also been carried out in recent studies. Taibi and Atmani (2017) applied the multi-criteria analysis integrated with GIS to rank the IZs in western Algeria. Pereira et al. (2008) scrutinized 
the site selection of IZs using the multi-criteria analysis method in combination with the GIS and fuzzy theory. Accordingly, the authors emphasized that transportation cost is the most important factor in site selection. Rikalovic et al. (2014) offered a suggestion that a multi-criteria analysis method based on the GIS should be used for site selection. With the application of GIS, the multi-criteria analysis process consists of two stages. The first stage is screening the options while the second stage is evaluating them. The steps vary from identifying problems, defining standards, scoring and standardizing, analyzing options using the GIS to weighting, combining standards and analyzing sensitiveness. Hence, the multi-criteria analysis method is generally employed in two interconnected approaches. The first approach specializes in the selection of production locations. The second approach focuses on the creation of a ranking of attractiveness. With decisions regarding investment site selection, the research methods are often used with GIS applications as well as a number of other techniques. For research related to ranking, this GIS might not be applied. It should be noted that the first approach itself intersects with the second one because, in order to select objects, we may need to rank them first. From the ranking, we can select the items (for example, investment location) with higher scores.

\subsection{Specific Methodology Employed for this Research}

We proposed in this study a five-step multi-criteria analysis method inherited and improved as follows:

Step 1: Collect and elaborate a comprehensive database of IZs. Because of the nonexistence of such a database in Viet Nam, we have to conduct a challenging task of building it from the beginning. The structure of the database encompasses four aggregate criteria and 17 sub-criteria (See Table 1). Four aggregate criteria are: (i) local economic environment; (ii) accessibility; (iii) infrastructure and services; and (iv) financial leasing expenses. Thus, we develop the new aggregate criterion of 'local economic environment' which covers the quality of local economic and administrative environment in order to reflect more precisely the attractiveness of the IZs at national level. Therefore, compared to Ramos and Fonseca (2016), the effort of the research group is to elaborate a full database at a national level rather than in only one region. The sources of input are very diverse including desk study, field surveys conducted in the North, the Central and the South of Viet Nam, in-depth interviews, interviews via telephone and internet, information from the provincial IZ management agency, website of IZs, information from state management agencies (Ministry of Planning and Investment, Maritime Administration), computed results of censuses of the General Statistics Office of Viet Nam, explorations based on Google Maps etc. For example, the infrastructure and service aggregate criterion includes four sub-criterion: whether there is a power station; whether there are alternative power sources, wastewater treatment capacity; and whether there is a customs office in the IZ or not. Those information can be collected via each IZ's website if available or using Google Maps. However, some 'unpublicized' or sometimes 'unclear' sub-criteria like Land rental price, Management fee, Price of clean water, Wastewater treatment price, Preferential corporate income tax needed more efforts with surveys conducted via emails, telephone calls or face-to-face interviews. Meanwhile, the 'District level industrial agglomeration' sub-criterion is the result of calculation from data collected in the nationwide database of the Vietnamese General Statistic Office. As a result, much improved and advanced from any previous study, this study developed a more extensive, inclusive and diversified database of IZs ready for an ideal selection of IZs.

Table 1. Criteria for ranking industrial zones' attractiveness

\begin{tabular}{|c|c|c|c|}
\hline $\begin{array}{c}\text { Local economic } \\
\text { environment }\end{array}$ & Accessibilities & Infrastructure and services & Financial leasing expenses \\
\hline$R_{\text {local }}\left(\underline{\sum(\text { Local }) \times 100}\right)$ & $\begin{array}{l}R_{\text {Access }} \\
\left(\underline{\sum(\text { Access }) \times 100}\right)\end{array}$ & $\begin{array}{l}R_{\text {Infra\&Serv }} \\
\quad\left(\sum(\text { Infra }) \times 100\right)\end{array}$ & $\begin{array}{l}R_{\text {Finance }} \\
=\left(\underline{\sum(\text { Finance }) \times 100}\right)\end{array}$ \\
\hline$=\left(\frac{-1}{4}\right)$ & $=\left(\frac{-1}{4}\right)$ & $=\left(\frac{4}{4}\right)$ & $=\left(\frac{-1}{5}\right)$ \\
\hline $\begin{array}{l}\text { ¿ Local: Sum of the local } \\
\text { economic environment } \\
\text { 4: components analyzed }\end{array}$ & $\begin{array}{l}\sum \text { Access: Sum of the } \\
\text { accessibility } \\
\text { 4: components analyzed }\end{array}$ & $\begin{array}{l}\sum \text { Infra \& Serv: Sum of } \\
\text { the infrastructure and } \\
\text { services } \\
\text { 4: components analyzed }\end{array}$ & $\begin{array}{l}\sum \text { Finance: : Sum of the finance } \\
\text { 5: components analyzed }\end{array}$ \\
\hline $\begin{array}{l}\text { - District level industrial } \\
\text { agglomeration } \\
\text { - Provincial competitiveness } \\
\text { index PCI (rank) } \\
\text { - Provincial GDP per person } \\
\text { (billion VND) } \\
\text { - Provincial GDP (billion VND) }\end{array}$ & $\begin{array}{l}\text { - Distance to the nearest } \\
\text { seaport }(\mathrm{km}) \\
\text { - Distance to the nearest } \\
\text { international airport }(\mathrm{km}) \\
\text { - Distance to the nearest city } \\
\text { center }(\mathrm{km}) \\
\text { - Distance to the nearest } \\
\text { train station }(\mathrm{km})\end{array}$ & $\begin{array}{l}\text { - Power station (yes / no) } \\
\text { - Alternate power source (yes } \\
\text { / no) } \\
\text { - Waste water treatment } \\
\text { capacity (m3 / ha) } \\
\text { - Customs office (yes / no) }\end{array}$ & $\begin{array}{l}\text { - Land rental price (USD/ha) } \\
\text { - Management fee (USD/ha) } \\
\text { - Price of clean water (USD/m3) } \\
\text { - Wastewater treatment price } \\
\text { (USD/m3) } \\
\text { - Preferential corporate income tax } \\
\text { (exemption for the first } 4 \text { years/ } \\
\text { exemption for the first } 2 \text { years/not } \\
\text { exempt) }\end{array}$ \\
\hline
\end{tabular}

Source: Developed from Ramos and Fonseca (2016)

Step 2: Compute the index (score) of the sub criteria for each IZ. The calculation methods vary between sub-criteria. For sub-criteria related to Infrastructure and Services, the score is computed as ' 1 ' if the infrastructure or service is available and ' 0 ' if it is unavailable. As regards to sub-criteria linked with Accessibility, first, this study uses Google Maps 
to find the distance from the IZ to the nearest seaport, airport, train station, city (Fernández and Ruiz, 2009; Louw and Bontekoning, 2007; UNIDO, 2012). Next, these distances are graded as 'Excellent' $=1$, 'Moderate' $=0.5$ and 'Bad' $=0$. The scoring method is based on the formula in Ramos and Mendes (2001) (('Excellent' if $D \leq\left(D_{\max } / 2\right)$, 'Moderate' if $\left(D_{\max } / 2\right)<\mathrm{D} \leq D_{\max }$, or 'Bad' if $\mathrm{D}>D_{\max }$ of which $\mathrm{D}$ is the distance from the IZ to the abovementioned locations). Computation results show that in Viet Nam the maximum distance $D_{\max }$ to railroad station equals to $99.50 \mathrm{~km}$, sea port to $128.84 \mathrm{~km}$, airport to $103.43 \mathrm{~km}$, and city center to $38.59 \mathrm{~km}$ (See Table 2).

Table 2. Examples of accessibility assessment of IZs

\begin{tabular}{|c|c|c|c|c|}
\hline Max. distance (km) & Accessibility & Excellent (1) & Moderate $(0,5)$ & Bad (0) \\
\hline$D_{\max }=\bar{x}_{j}+\sigma_{j}$ & & $\mathrm{D} \leq \mathrm{D}_{\max } / 2$ & $\mathrm{D}_{\max } / 2<\mathrm{D} \leq \mathrm{D}_{\max }$ & $\mathrm{D}>\mathrm{D}_{\max }$ \\
\hline 99.50 & Railroad station & $\mathrm{D} \leq 49.75$ & $49.75<\mathrm{D} \leq 99.50$ & $\mathrm{D}>99.5$ \\
\hline 103.43 & Airport & $\mathrm{D} \leq 51.71$ & $51.715<\mathrm{D} \leq 103.43$ & $\mathrm{D}>103.43$ \\
\hline 128.84 & Sea port & $\mathrm{D} \leq 64.42$ & $64.42<\mathrm{D} \leq 128.84$ & $\mathrm{D}>128.84$ \\
\hline 38.59 & City center & $\mathrm{D} \leq 19.29$ & $19.29<\mathrm{D} \leq 38.59$ & $\mathrm{D}>38.59$ \\
\hline
\end{tabular}

Source: Authors' calculations based on Vietnamese data

Note: $\bar{x}_{j}$ is the average value of criterion $\mathrm{j}$ over all industrial zone; $\sigma_{j}$ is the standard deviation of criterion $\mathrm{j}$ over all industrial zone

For other sub-criteria related to the aggregate criteria such as the "Local business environment" and the "Financial expenses of land lease", we use the same method to find out the score of each sub-criterion. From the scores of the sub criteria, we then compute the scores for the aggregate criteria. The scores of the aggregate criteria are equal to the average of the sub-spending scores. The result of this step is that each aggregate criterion of each IZ has a score.

Step 3: Employ the multi-criteria analysis. First of all, apply the scoring scenarios of each IZ based on the change in weight for each aggregate criterion. The applied weights depend on the interest of the evaluator, and we thus divide them into five scenarios accordingly. For Scenario 1, the weights are evenly distributed among the four aggregate criteria $(0.25,0.25,0.25,0.25)$. For Scenario 2 , more weight is applied for Infrastructure and Services while equal weight is applied to other criteria $(0.4,0.2,0.2,0.2)$. In Scenario 3, more weight for Accessibility and equal weight to other remaining criteria $(0.2,0.4,0.2,0.2)$. Meanwhile, the Accessibility criterion is the most important aggregate criterion for Scenario 3. Therefore, in Scenario 3, the aggregate criterion of Accessibility is more weighted (0.2; $0,4 ; 0,2 ; 0,2)$. Similarly, in Scenario 4, the aggregate criterion of Local economic environment is more weighted $(0.2 ; 0.2$; $0.4 ; 0.2)$. Finally, in Scenario 5 , the aggregate criterion of Financial leasing cost is the most significant weighted $(0.2$; $0.2 ; 0.2 ; 0.4)$.

Step 4: Convert the scores of each scenario into a scale of 0, 5, 10 and 20 (See Table 3).

Step 5: Compute score for each IZ by totaling up the scores (which are already converted into a scale of $(0,5,10$,
20 ) in Step 4) of the scenarios and then make a ranking of the IZs. IZs with high scores will be ranked high and vice versa.

Table 3. Examples of partial scoring of industrial zones

\begin{tabular}{|c|}
\hline $\operatorname{Score}_{i, j}<\left(\bar{x}_{j}-\sigma_{j}\right) \Rightarrow$ Score $_{i, j}=\mathbf{0}$ \\
\hline $\begin{aligned}\left(\bar{x}_{j}-\left(\bar{x}_{j}+\sigma_{j}\right)\right) & >S \operatorname{scor} e_{i} \geq\left(\bar{x}_{j}-\sigma_{j}\right) \Rightarrow \text { Score }_{i, j} \\
& =5\end{aligned}$ \\
\hline $\begin{array}{c}\left(\bar{x}_{j}+\sigma_{j}\right)>\text { Score }_{i, j} \geq\left(\bar{x}_{j}-\left(\bar{x}_{j}+\sigma_{j}\right)\right) \Rightarrow \text { Score }_{i, j} \\
=10\end{array}$ \\
\hline Score $_{i, j} \geq\left(\bar{x}_{j}+\sigma_{j}\right) \Rightarrow$ Score $_{i, j}=20$ \\
\hline $\begin{array}{l}\text { Score }_{i, j} \text { Performance of each zone (i) in each scenario (j), } \\
\text { where } i=1 \text { to } n \text { and } j=1 \text { to } 5 \\
n \text { is the number of zones } \\
\bar{x}_{j} \text { is the Global average obtained by all the zones in each } \\
\text { scenario }(j), j=1 \text { to } 5 \text {. } \\
\sigma_{j} \text { is the Standard deviation obtained by all the zones in each } \\
\text { scenario }(j), j=1 \text { to } 5 \text {. }\end{array}$ \\
\hline
\end{tabular}

Source: Ramos and Fonseca (2016)

\subsection{Results and Findings}

We collected data of all 326 IZs across Viet Nam (till by the end of 2018). However, only $257 \mathrm{IZs}$ were able to provide full data as requested for the study. These IZs are the most important ones in Viet Nam and we covered them all for ranking. Since the four criteria of IZs are weighted and scored according to the scenario, the final ranking will be a linear combination of trade-offs between the four different scenarios (see Table 4). 
Table 4. Descriptive statistics

\begin{tabular}{|c|c|c|c|c|c|c|}
\hline Factors & Variables & Obs & Mean & St.dev & Mean & Max \\
\hline \multirow{4}{*}{$\begin{array}{l}\text { Accessibility } \\
\text { Factor }\end{array}$} & distance_port & 257 & 54.16 & 49.93 & 0.50 & 230.00 \\
\hline & distance_airport & 257 & 49.78 & 41.41 & 2.00 & 241.00 \\
\hline & distance_city & 257 & 20.75 & 16.00 & 1.00 & 100.00 \\
\hline & distance_train & 257 & 41.63 & 49.48 & 0.4 & 266 \\
\hline \multirow{4}{*}{ Local economy } & Agglomeration & 257 & 9.55 & 1.51 & 4.83 & 14.74 \\
\hline & Pci & 257 & 21.48 & 16.95 & 1.00 & 63.00 \\
\hline & Grdp & 257 & 185326.00 & 224375.60 & 12152.29 & 778158.00 \\
\hline & grdp_per_capita & 257 & 67.66 & 46.07 & 22.04 & 231.51 \\
\hline \multirow{4}{*}{$\begin{array}{l}\text { Infrastructure } \\
\text { and Services }\end{array}$} & electricity_source & 257 & 0.89 & 0.31 & 0.00 & 1.00 \\
\hline & alternative_elec & 257 & 0.26 & 0.44 & 0.00 & 1.00 \\
\hline & wastewater_capaci & 257 & 4689.33 & 2863.98 & 200.00 & 12000.00 \\
\hline & Custom & 257 & 0.34 & 0.47 & 0.00 & 1.00 \\
\hline \multirow{5}{*}{ Finance } & free_tax_4 & 257 & 0.59 & 0.28 & 0.00 & 1.00 \\
\hline & rent_per_year & 257 & 1.60 & 1.77 & 0.01 & 25.00 \\
\hline & management_fee & 257 & 0.38 & 0.28 & 0.01 & 3.50 \\
\hline & water_price & 257 & 0.42 & 0.12 & 0.17 & 0.76 \\
\hline & wastewater_treat_price & 257 & 0.33 & 0.11 & 0.12 & 0.90 \\
\hline
\end{tabular}

Source: Compiled by the authors

Therefore, if an IZ scored imperfectly in one criterion, it can still have an overall attractiveness score of 100 , thanks to the high scores in the remaining criteria. For instance, Hiep Phuoc IZ (phase 2) has a significantly high rent cost of over 100 USD per hector in full-time of operation that means it is unattractive to some investors. However, because the IZ is located next to Hiep Phuoc port, its Accessibility score is superb. As a result, the IZ is ranked in the group with the highest attractiveness.

The results are then analyzed by region, source of capital for IZ development, province/city and IZ operational status. The attractiveness of each IZ is determined based on the overall score of that zone, ranging from 0 to 100 . The higher the total scores of the IZ, the more attractive to investors. The average score of Viet Nam's IZs is 42.33, which is below the average. The South East region took the lead with an average score of 51.70. Following are the three regions: the Red River Delta, the Central Coast and the Mekong Delta. The most unattractive areas are the Northern Midlands and Mountains and the Central Highlands. Besides, there remain unattractive IZs in each region with the score of 0 . Thus, the region where the IZ is located has a certain influence on the attractiveness of the IZ (see Table 5).

It seems that the foreign factor in the type of owner makes an IZ more attractive than the private and state-owned ones. The quality of IZs with foreign investors is more consistent than others (there are no IZs having a score of 0 ) (see Table 6).
Table 5. Results of IZ ranking by region

\begin{tabular}{|c|c|c|c|c|c|}
\hline Region & $\mathbf{N}$ & mean & sd & $\max$ & $\min$ \\
\hline Southeast & 124 & 51.73 & 29.49 & 100 & 0 \\
\hline Red river delta & 53 & 38.39 & 25.92 & 100 & 0 \\
\hline Central coast & 34 & 36.47 & 18.03 & 80 & 0 \\
\hline Mekong delta & 27 & 35.37 & 17.70 & 90 & 0 \\
\hline $\begin{array}{l}\text { Northern Midlands } \\
\text { and Mountains }\end{array}$ & 14 & 16.07 & 16.66 & 60 & 0 \\
\hline Central Highlands & 5 & 2.00 & 4.47 & 10 & 0 \\
\hline
\end{tabular}

Source: compiled by the authors

Table 6. Results of IZ ranking by ownership type

\begin{tabular}{llllll}
\hline Ownership type & $\mathbf{N}$ & mean & sd & $\max$ & $\min$ \\
\hline Joint-venture & 16 & 62.18 & 32.45 & 100 & 0 \\
\hline $\mathbf{1 0 0 \%}$ foreign & 14 & 46.78 & 25.31 & 100 & 20 \\
\hline Private & 162 & 42.84 & 27.68 & 100 & 0 \\
\hline State-owned & 65 & 35.23 & 24.71 & 100 & 0
\end{tabular}

Source: Compiled by the authors

Besides, the operational status of IZs also presents a relationship with the attractiveness of IZs. Expanding and operating IZs prove to be more likely to build trust with investors than IZs which are under construction due to clear and concrete results of infrastructure and services (see Table 7). 
Table 7. Results of Iz ranking by operational status

\begin{tabular}{|c|c|c|c|c|c|}
\hline Status & $\mathbf{N}$ & mean & sd & $\max$ & $\min$ \\
\hline $\begin{array}{l}\text { Expanding } \\
\text { Operating }\end{array}$ & -9 & 56.11 & 30.08 & 100 & 20 \\
\hline Operating & 209 & 43.99 & 28.05 & 100 & 0 \\
\hline $\begin{array}{l}\text { Expanding } \\
\text { Building }\end{array}$ & - 13 & 34.23 & 23.70 & 90 & 0 \\
\hline Building & 25 & 29.40 & 20.12 & 60 & 0 \\
\hline Withdrawing & 1 & 0.00 & 0.00 & 0 & 0 \\
\hline
\end{tabular}

Source: Compiled by the authors

In terms of administrative boundaries, there are 6 localities in the leading group: Ho Chi Minh City, Da Nang, Binh Duong, Bac Ninh, Ba Ria-Vung Tau, and Quang Ninh. Ho Chi Minh City is the city that has the most attractive IZs for investors (on average 77.72 out of 100 scores). It is not surprising because this is the first province in Viet Nam to develop the IZ model in the mid-1990s, as well as being the economically leading city equipped with convenient transportation, acceptable infrastructure, and capable and skillful human resources. A number of the least unattractive IZs are located in mountainous provinces (with the score of zero) such as Kon Tum, Lam Dong, Lang Son, Dak Lak, Dak Nong and Hoa Binh. These provinces have only one industrial zone, and those industrial zones are scored 0 for attractiveness. Thus, the province's "mean", "min" and "max" values would be 0 . Moreover, as there is only one industrial zone or observation, the "standard deviation" will be missing and recorded as "." (see Table 8).

Table 8. Results of IZ ranking by province

\begin{tabular}{llllll}
\hline Province & N & mean & sd & max & min \\
\hline Hồ Chí Minh & 22 & 77.73 & 18.56 & 100 & 40 \\
\hline Đà Năng & 4 & 70 & 14.14 & 80 & 50 \\
\hline Bình Dương & 29 & 63.79 & 30.14 & 100 & 5 \\
\hline Bắc Ninh & 11 & 60.45 & 23.29 & 100 & 35 \\
\hline Quảng Ninh & 4 & 60 & 20.41 & 90 & 45 \\
\hline Bà Ria-Vũng & 13 & 55.76 & 21.49 & 100 & 30 \\
Tàu & & & & & \\
\hline Hà Nội & 11 & 48.64 & 23.25 & 90 & 25 \\
\hline Đồng Tháp & 3 & 48.33 & 36.17 & 90 & 25 \\
\hline Hải Phòng & 2 & 47.5 & 3.534 & 50 & 45 \\
\hline Cần Thơ & 9 & 45.56 & 12.36 & 60 & 30 \\
\hline Khánh Hòa & 1 & 45 &. & 45 & 45 \\
\hline Quảng Nam & 2 & 45 & 7.07 & 50 & 40 \\
\hline Đồng Nai & 28 & 43.57 & 21.68 & 100 & 5 \\
\hline Quảng Ngãi & 4 & 41.25 & 28.39 & 60 & 0 \\
\hline Long An & 17 & 40.29 & 19.96 & 100 & 15 \\
\hline Tây Ninh & 5 & 39 & 18.17 & 60 & 20 \\
\hline Vĩnh Phúc & 6 & 38.33 & 14.02 & 60 & 25 \\
\hline Tiền Giang & 3 & 36.67 & 7.64 & 45 & 30 \\
\hline Nghệ An & 1 & 35 &. & 35 & 35 \\
\hline Sóc Trăng & 1 & 35 &. & 35 & 35 \\
\hline Trà Vinh & 1 & 35 &. & 35 & 35 \\
\hline & & & & & \\
\hline & & & & \\
\hline
\end{tabular}

Table 8. Results of IZ ranking by province (con't)

\begin{tabular}{|c|c|c|c|c|c|}
\hline Province & $\mathbf{N}$ & mean & sd & $\max$ & $\min$ \\
\hline Bắc Giang & 4 & 33.75 & 17.97 & 60 & 20 \\
\hline Bình Thuận & 5 & 33 & 6.708 & 40 & 25 \\
\hline Phú Yên & 3 & 31.67 & 12.58 & 45 & 20 \\
\hline Bến Tre & 2 & 30 & 0 & 30 & 30 \\
\hline Hà Tĩnh & 1 & 30 & . & 30 & 30 \\
\hline Hậu Giang & 2 & 30 & 0 & 30 & 30 \\
\hline Quảng Bình & 1 & 30 & . & 30 & 30 \\
\hline $\begin{array}{l}\text { Thừa Thiên } \\
\text { Huế }\end{array}$ & 4 & 28.75 & 7.50 & 40 & 25 \\
\hline Thanh Hóa & 3 & 28.33 & 2.89 & 30 & 25 \\
\hline Ninh Thuận & 1 & 25 & . & 25 & 25 \\
\hline Vĩnh Long & 3 & 25 & 0 & 25 & 25 \\
\hline Hà Nam & 6 & 21.67 & 8.16 & 35 & 15 \\
\hline Bình Định & 4 & 20 & 10 & 25 & 5 \\
\hline Nam Định & 1 & 20 & . & 20 & 20 \\
\hline Thái Nguyên & 2 & 20 & 0 & 20 & 20 \\
\hline Hải Dương & 7 & 15 & 11.55 & 35 & 0 \\
\hline Phú Thọ & 4 & 11.25 & 11.09 & 25 & 0 \\
\hline Bạc Liêu & 1 & 10 & . & 10 & 10 \\
\hline Gia Lai & 1 & 10 & . & 10 & 10 \\
\hline Tuyên Quang & 1 & 5 & . & 5 & 5 \\
\hline Bình Phước & 10 & 3 & 6.75 & 20 & 0 \\
\hline Hưng Yên & 5 & 3 & 4.47 & 10 & 0 \\
\hline Hoà Bình & 2 & 0 & 0 & 0 & 0 \\
\hline Kon Tum & 1 & 0 & . & 0 & 0 \\
\hline Lâm Đồng & 1 & 0 & . & 0 & 0 \\
\hline Lạng Sơn & 1 & 0 & . & 0 & 0 \\
\hline Đắk Lắk & 1 & 0 & . & 0 & 0 \\
\hline Đắk Nông & 1 & 0 & . & 0 & 0 \\
\hline
\end{tabular}

Source: Compiled by the authors

It is noteworthy that the ranking of Viet Nam's IZs by each zone represents a great difference in terms of attractiveness level. There are $20 \mathrm{IZs}$ with an absolute rating (100 points) and $22 \mathrm{IZs}$ that are completely unappealing based on any criteria. The most attractive IZs are characterized by excellent infrastructure and services, smooth accessibility, favorable local economic environment for production and business, and acceptable financial leasing expenses. These IZs have a common feature of having a long operating history (some have been operating since the 1990s), mainly developed by domestic private investors. Of this group, Singapore is the only foreign infrastructure development partner. Because of entering the market early, these IZs could easily find favorable locations and create a high attraction for businesses. On the other hand, preferential policies and mechanisms applied to the construction of IZs' infrastructure as well as tax exemptions for manufacturing enterprises in the first phase of the IZs also add to the attractiveness of these zones. Of the 20 leading IZs, only two are located in the North (VSIP and Tien Son in Bac Ninh), the remaining are completely in the Southeast region (see Table 9). 
Table 9. Industrial zones with the highest and lowest attractiveness scores

\begin{tabular}{|c|c|c|c|c|c|c|}
\hline No & Name of IZ & $\begin{array}{l}\text { Accessibility } \\
\text { score }\end{array}$ & $\begin{array}{l}\text { Local economic } \\
\text { score }\end{array}$ & $\begin{array}{l}\text { Infrastructure and } \\
\text { services score }\end{array}$ & $\begin{array}{l}\text { Financial } \\
\text { leasing } \\
\text { expenses } \\
\text { score }\end{array}$ & Total \\
\hline 1 & VSIP (Bắc Ninh) & 87.5 & 62.5 & 87.5 & 50 & 100 \\
\hline 2 & Hiệp Phước (phase 2) & 100 & 75 & 62.5 & 50 & 100 \\
\hline 3 & Nam Tân Uyên & 100 & 75 & 75 & 70 & 100 \\
\hline 4 & VSIP (Bình Dương) & 100 & 75 & 75 & 50 & 100 \\
\hline 5 & Tân Đức & 87.5 & 50 & 75 & 80 & 100 \\
\hline 6 & Tiên Sơn & 87.5 & 62.5 & 62.5 & 70 & 100 \\
\hline 7 & Tam Phước & 87.5 & 62.5 & 50 & 90 & 100 \\
\hline 8 & Nhơn Trạch V & 87.5 & 50 & 62.5 & 90 & 100 \\
\hline 9 & Sóng Thần II & 100 & 62.5 & 75 & 70 & 100 \\
\hline 10 & Cái Mép & 87.5 & 75 & 62.5 & 70 & 100 \\
\hline 11 & Tân Đông Hiệp A & 100 & 62.5 & 50 & 70 & 100 \\
\hline 12 & Đông Xuyên & 87.5 & 75 & 50 & 70 & 100 \\
\hline 13 & VSIP II A & 100 & 75 & 62.5 & 50 & 100 \\
\hline 14 & VSIP II & 100 & 75 & 62.5 & 50 & 100 \\
\hline 15 & Mapletree & 100 & 75 & 50 & 70 & 100 \\
\hline 16 & Lê Minh Xuân & 100 & 87.5 & 62.5 & 70 & 100 \\
\hline 17 & Tân Đông Hiệp B & 100 & 62.5 & 62.5 & 70 & 100 \\
\hline 18 & Đông Nam & 100 & 75 & 75 & 60 & 100 \\
\hline 19 & Sóng Thần III & 100 & 75 & 37.5 & 80 & 100 \\
\hline 20 & Tân Tạo (expanded) & 100 & 87.5 & 37.5 & 70 & 100 \\
\hline$\ldots$ & $\ldots$ & $\ldots$ & $\ldots$ & $\ldots$ & $\ldots$ & $\ldots$ \\
\hline 238 & Đồng Xoài II & 50 & 12.5 & 25 & 60 & 0 \\
\hline 239 & Lai Cách & 75 & 12.5 & 25 & 60 & 0 \\
\hline 240 & Đồng Bành & 25 & 0 & 25 & 60 & 0 \\
\hline 241 & Tâm Thắng & 12.5 & 12.5 & 37.5 & 70 & 0 \\
\hline 242 & Thăng Long II & 75 & 12.5 & 37.5 & 40 & 0 \\
\hline 243 & Chơn Thành II & 50 & 12.5 & 25 & 50 & 0 \\
\hline 244 & Bờ trái sông Đà & 37.5 & 12.5 & 25 & 60 & 0 \\
\hline 245 & Binh Long & 25 & 25 & 25 & 80 & 0 \\
\hline 246 & Hòa Bình (phase1) & 25 & 12.5 & 50 & 80 & 0 \\
\hline 247 & Thuy. Vân & 62.5 & 25 & 25 & 60 & 0 \\
\hline 248 & Lương Sơn & 62.5 & 12.5 & 25 & 60 & 0 \\
\hline 249 & Yên Mỹ 2 (phase 1) & 62.5 & 12.5 & 37.5 & 50 & 0 \\
\hline 250 & Phổ Phong & 50 & 25 & 25 & 70 & 0 \\
\hline 251 & Việt Kiều & 25 & 12.5 & 0 & 60 & 0 \\
\hline 252 & Đồng Xoài I & 50 & 12.5 & 25 & 60 & 0 \\
\hline 253 & Đồng Xoài III & 62.5 & 12.5 & 37.5 & 60 & 0 \\
\hline 254 & Becamex-Bình Phước & 37.5 & 12.5 & 37.5 & 60 & 0 \\
\hline 255 & Hòa Phú & 25 & 25 & 50 & 50 & 0 \\
\hline 256 & Minh Đức & 62.5 & 12.5 & 12.5 & 60 & 0 \\
\hline 257 & Lộc Sơn & 25 & 25 & 50 & 70 & 0 \\
\hline
\end{tabular}

Source: Compiled by the authors (full table could be provided upon request) 
In short, this is the pioneering ranking of IZs in Viet Nam based on their attractiveness. The ranking encompasses most of the existing IZs in the country. In order to rank the IZs, a meticulous and comprehensively updated database of Viet Nam's IZs at both macro and micro levels covering accessibility, infrastructure, services, financial expenses and local economic environment has been found. The IZs' ranking could be utilized for a variety of purposes. Investors could employ the ranking as a dependable basis in selecting IZs to locate their projects. When it comes to IZ infrastructure developers, this ranking could be a trustworthy source of information for selfassessment of their competitiveness to improve their business plans. Finally, as for policy makers, this classification could be adopted as a useful reference for IZs' planning in parallel with regional development policies at both central and local levels.

\section{CONCLUSION AND IMPLICATIONS}

It has been challenging for enterprises, IZs' infrastructure developers, policy-makers and other users to assess the competence of IZs in Viet Nam for their location decisions due to the substantial number of IZs, the insufficiency of information of IZs, the lack of suitable and reliable ranking methods and the absence of a ready-made ranking of all IZs in Viet Nam. This study has overcome these obstacles. This paper is the first ever to successfully conduct a considerable database constructed at both macro and micro levels, including local economic environment, accessibility, infrastructure and financial expenses. From this database, the study applied the multi-criteria analysis method to rank the IZs in Viet Nam to satisfy different interests of users. Thus, this study has for the first time identified precisely the 'attractiveness' levels of the existing IZs based on their own characteristics, or in other words, making a useful ranking of IZs nationwide.

To accomplish these abovementioned tasks, the research first investigated theories related to IZs and IZ location decisions. Developing IZs is substantiated to yield a number of benefits for enterprises because IZs meet the demands of enterprises in terms of infrastructure or actualize the spill-over effects. The theory of location decisions in general and IZ selection in particular, emphasizes that location selection depends on the attractiveness of the place. Factors such as infrastructure, transportation costs, markets, policies etc., are shown to be examined by investors before they come to the decision of where to invest.

This study also scrutinized the development of Vietnamese IZs. IZs are indicated to play an increasingly significant role in the economy through providing industrial infrastructure for enterprises and separating industrial production facilities from residential areas. Projects in IZs account for a large proportion of FDI attraction, substantial job creation for the economy, and a remarkable contribution to the state budget. By applying and improving the multicriteria analysis method to rank IZs, the study employed four aggregate criteria to measure the attractiveness of IZs, namely Local economic environment, Infrastructure and services, Accessibility, and Financial leasing expenses. The attractiveness of IZs is measured in five categories of the IZ itself, city/province, region, ownership of the IZ, and operating status of the IZ.
In general, the attractiveness scores among IZs are diversified. Several IZs are well-favoured with high attractiveness scores, whereas others are completely unattractive with zero scores. Most of high-scored IZs have the common characteristics of concentrating in the Southeast region, being developed or operated by foreign infrastructure developers, and being put into operation or expansion.

It should be noted that this ranking is 'static' at a specific time. In fact, the attractiveness of each IZ can change over time for many reasons. It might be due to proactive reasons, such as the IZs themselves improve the quality of infrastructure and reduce service prices. On the contrary, this change may be due to passive causes such as changes in the total number of IZs, or due to improvement in accessibility of the IZs (for instance, new roads, new railway system, airports are opened near IZs), or because the local economic environment becomes better or worse. Therefore, updating this ranking periodically to analyze the changes in attractiveness scores of IZs over time is indispensable. On the other hand, the number of aggregate criteria as well as the sub criteria used in the multi-criteria analysis method might fluctuate over time to be capable of evaluating the attractiveness of IZs in the most expedient way.

The score of the attractiveness of each IZ in a region when gathered together showcases the attractiveness of the IZ at the regional level. The attractiveness score of IZs by region exhibits an imbalance in the level of regional development in Viet Nam. Although the attractiveness of IZs varies among regions, it does not mean that the regions with high IZs attractiveness scores are all attractive to investors. On the contrary, in such areas, there still exist IZs with low attractiveness scores and, therefore, the competition among IZs in such places is often very harsh.

The ranking shows that in general, the attractiveness of IZs that have been put into operation is higher than that of new IZs. In other words, there is a great pressure on new IZs to attract investment. Therefore, this ranking could be used in IZs planning. Moreover, using IZs as a regional development tool should be decided with more careful consideration.

On the other hand, the knowledge of IZ raking may also contribute to the development of value chains. The fact is that many companies want to become suppliers or customers of other companies in IZs. For example, companies want to become suppliers or customers of multinational companies such as Samsung, LG, Canon, Honda in Viet Nam, and these multinational companies and their subsidiaries tend to gather in one or more nearby IZs. At this stage, information regarding IZs raking can be used by enterprises to choose the most appropriate location when engaging in the desired value chain.

Finally, this study provides a ranking of IZs by attractiveness score that could be widely used in future studies, for instance, study to find out the relationship between the ranking of IZs attractiveness scores and socioeconomic indicators of the region (even each district level) where the IZ is located. As stated above, scores of attractiveness of IZs can change over time. When finding the link between the attractiveness of the IZ and the regional socio-economic indicators, the enhancement of this attraction has a more positive meaning not only for IZs in competition with other IZs but also for a sustainable and long-lasting regional development. 


\section{ACKNOWLEDGEMENT}

We would like to thank research fellows at Viet Nam Institute for Economic and Policy Research (VEPR): Pham Van Dai, Nguyen Minh Long, Pham Thi Huong, Nguyen Thi Thuy Hang, and Le Thi Minh Hien at Viet Nam Center for Economic and Strategic Studies (VESS), Dr. Hoang Xuan Trung at Viet Nam Academy for Social Sciences (VASS) for their support and advices in different stages of the study.

This research is funded by Viet Nam's National Foundation for Science and Technology Development (NAFOSTED) under grant number 502.99-2016.13.

\section{REFERENCES}

Arauzo-Carod, J. M., Liviano-Solis, D., and Manjón-Antolín, M. (2010). Empirical studies in industrial location: an assessment of their methods and results. Journal of regional science, 50(3), pp. 685-711.

Badri, M. A. (2007). Dimensions of industrial location factors: review and exploration. Jornal of Business and public affairs, 1(2), pp. 1-26.

Becker, R., and Henderson, V. (2000). Effects of air quality regulations on polluting industries. Journal of Political Economy, 108(2), pp. 379-421.

Belussi, F., and Caldari, K. (2009). At the origin of the industrial district: Alfred Marshall and the Cambridge school. Cambridge Journal of Economics, 33(2), pp. 335-355.

Christaller, W. (1966). Central places in southern Germany (Vol. 10): Prentice-Hall.

Dunning, J. H., and Lundan, S. M. (2008). Multinational enterprises and the global economy: Edward Elgar Publishing.

Fernández, I., and Ruiz, M. (2009). Descriptive model and evaluation system to locate sustainable industrial areas. Journal of Cleaner Production, 17(1), pp. 87-100.

Friedman, J., Gerlowski, D. A., and Silberman, J. (1992). What attracts foreign multinational corporations? Evidence from branch plant location in the United States. Journal of regional science, 32(4), pp. 403-418.

Gabe, T. M., and Bell, K. P. (2004). Tradeoffs between local taxes and government spending as determinants of business location. Journal of regional science, 44(1), pp. 21-41.

Gholamian, M., and Nasri, M. (2019). A Multi Echelon LocationInventory Model with Lateral Transshipment. Operations and Supply Chain Management: An International Journal, 12(2), pp. 88-99.

Greenhut, M. L. (1956). Plant location in theory and in practice; the economics of space: Chapel Hill: University of North Carolina Press.

Hoffman, J. J., and Schniederjans, M. J. (1994). A two-stage model for structuring global facility site selection decisions. International Journal of Operations \& Production Management, pp. 79-96.

Hoover, E. M. (1948). Location of economic activity: McGraw-Hill Book Company, Inc., New York.

Knack, S., and Keefer, P. (1995). Institutions and economic performance: cross-country tests using alternative institutional measures. Economics \& Politics, 7(3), pp. 207227.

Kobayashi, T., Khojasteh, Y., and Kainuma, Y. (2019). Analysis of Multi-objective Decision Problems in Humanitarian Supply Chains. Operations and Supply Chain Management: An International Journal, 12(2), pp. 60-67.

Krugman, P. R. (1991). Geography and trade: MIT press.

Kušar, S. (2011). The Institutional Approach in Economic Geography: an Applicative View. Croatian Geographical Bulletin, 73(1), pp. 39-49.
Launhardt, W. (1993). Mathematical principles of economics / Wilhelm Launhardt ; translated by Hilda Schmidt ; edited and with an introduction by John Creedy: Hants: Edward Publishing Limited.

List, J. A., and McHone, W. W. (2000). Measuring the effects of air quality regulations on "dirty" firm births: Evidence from the neo-and mature-regulatory periods. Papers in Regional Science, 79(2), pp. 177-190.

Lösch, A. (1978). The economics of location, trans: Yale University Press, New Haven.

Louw, E., and Bontekoning, Y. (2007). Planning of industrial land in the Netherlands: its rationales and consequences. Tijdschrift voor Economische en Sociale Geografie, 98(1), pp. 121-129.

Maroto, A., and Zofío, J. L. (2016). Accessibility gains and road transport infrastructure in Spain: A productivity approach based on the Malmquist index. Journal of Transport Geography, 52, pp. 143-152.

Marshall, A. (2009). Principles of economics: unabridged eighth edition: Cosimo, Inc.

Mauro, P. (1995). Corruption and growth. The quarterly journal of economics, 110(3), pp. 681-712.

Mokrini, A., Boulaksil, Y., and Berrado, A. (2019). Modelling facility location problems in emerging markets: The case of the public healthcare sector in Morocco. Operations and Supply Chain Management: An International Journal, 12(2), pp. 100-111.

Mota, I., and Brandão, A. (2013). The determinants of location choice: Single plants versus multi-plants. Papers in Regional Science, 92(1), pp. 31-49.

Nguyen D. Thanh, Pham V. Dai and Vu M. Long (2019). Developing methodology framework for ranking industrial zones in Viet Nam. Tạp chí Nghiên cứu Kinh tế (Monthly Review of Economic Studies), 59(8), pp. 3-11.

Pereira, S. H. d. F., Calijuri, M. L., Pereira, S. C. M., Bezerra, N. R., and Macedo, M. d. N. C. d. (2008). A multicriteria-based location of an industrial park in a defined area in Ipatinga, Minas Gerais State, Brazil. Sociedade \& Natureza, 20(1), pp. 139-159.

Ramos, R. A. R., and Fonseca, F. P. (2016). A methodology to identify a network of industrial parks in the Ave valley, Portugal. European Planning Studies, 24(10), pp. 1844-1862.

Ramos, R. A. R., and Mendes, J. F. (2001). Avaliação da aptidão do solo para localização industrial: o caso de Valença [Evaluation of soil suitability for industrial location: the case of Valença]. Engenharia Civil, 10, pp. 7-29.

Rikalovic, A., Cosic, I., and Lazarevic, D. (2014). GIS based multicriteria analysis for industrial site selection. Procedia engineering, 69(12), pp. 1054-1063.

Sachs, J. D., and Warner, A. M. (1997). Fundamental sources of long-run growth. The American economic review, 87(2), pp. 184-188.

Samuelson, P. A. (1938). A note on the pure theory of consumer's behaviour. Economica, 5(17), pp. 61-71.

Snyder, C., and Nicholson, W. (2008). Microeconomic theory: Thomson South-Western, Canada.

Taibi, A., and Atmani, B. (2017). Combining Fuzzy AHP with GIS and Decision Rules for Industrial Site Selection. International Journal of Interactive Multimedia \& Artificial Intelligence, 4(6), pp. 60-69.

Tellier, L. N., and Vertefeuille, C. (1995). Understanding spatial inertia: center of gravity, population densities, the Weber problem, and gravity potential. Journal of regional science, 35(1), pp. 155-164.

UNIDO. (1997). Industrial estates: principles and practices. Retrieved from Vienna, Austria:

UNIDO. (2012). Europe and Central Asia Regional Conference on Industrial Parks as a Tool to Foster Local Industrial Development. Baku, Azerbaijan. 
Velasquez, M., and Hester, P. T. (2013). An analysis of multicriteria decision making methods. International journal of operations research, 10(2), pp. 56-66.

Vidová, J. (2010). Industrial parks-history, present and its Influence to the Employment. Review of economic perspectives, 10(1), pp. 41-58.

Vietnamese Ministry of Planning and Investment. (2017). Báo cáo tổng kết hoạt động các mô hình Khu công nghiệp, Khu kinh tế [Summary report on models of industrial parks and economic zones]. Hanoi, Vietnam

Vietnamese Ministry of Planning and Investment. (2018). Báo cáo tình hình thành lập và phát triển Khu công nghiệp, Khu kinh tế năm 2018 [Report on establishment and development of industrial parks and economic zones in 2018]. Hanoi, Vietnam
Vietnamese Ministry of Planning and Investment. (2019). Báo cáo tình hình thành lập và phát triển Khu công nghiệp, Khu kinh tế 6 tháng đầu năm 2019 [Report on establishment and development of industrial parks and economic zones in the first 6 months of 2019]. Hanoi, Vietnam

Von Thunen, J. H. (1966). Von Thunen's Isolated State: An English Edition of Der Isolierte Staat/ Johann Heinrich Von Thunen (C. M. Wartenberg, Trans. P. Hall Ed.): Pergamon.

Weber, A. (1929). Theory of the Location of Industries: University of Chicago Press.

Woodward, D. P. (1992). Locational determinants of Japanese manufacturing start-ups in the United States. Southern Economic Journal, pp. 690-708.

Assoc. Prof. NGUYEN Duc-Thanh is the founder and chief executive officer of the Viet Nam Center for Economic and Strategic Studies (VESS), a think tank founded in Ha Noi in 2020. He was the founding president of the Viet Nam Institute for Economic and Policy Research (VEPR), University of Economic and Business, Vietnam National University - Ha Noi during 2008-2020. He received his PhD in Development Economics from the National Graduate Institute for Policy Studies (GRIPS), Tokyo, Japan.

Dr. LE Huong-Linh is a lecturer at the International School, Vietnam National University, Ha Noi. She received her PhD in Economics and Management from Tohoku University, Japan. She currently teaches macroeconomics and international trade management. Her research interest includes industrial development, regional development and international trade.

Ms. BUI Thi Thuy Linh is a research fellow at the Viet Nam Institute for Economic and Policy Research (VEPR), Ha Noi. She received her BA in Investment Economics from the National Economics University (NEU), Ha Noi, Viet Nam. 